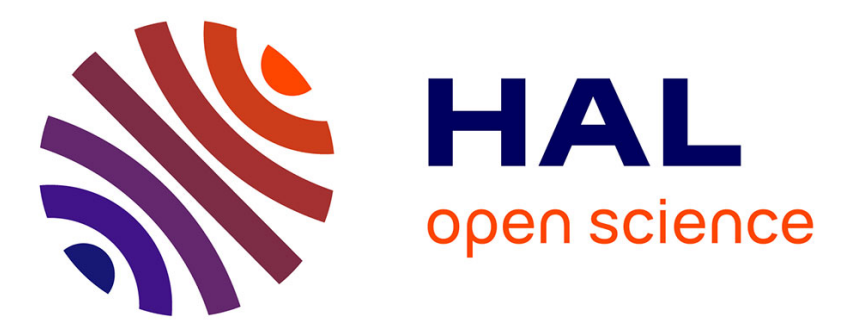

\title{
Clonal variation in heartwood norlignans of Cryptomeria japonica: evidence for independent control of agatharesinol and sequirin $\mathrm{C}$ biosynthesis
}

Bito, Nakada, Fukatsu, Matsushita, Fukushima, Imai

\section{- To cite this version:}

Bito, Nakada, Fukatsu, Matsushita, Fukushima, et al.. Clonal variation in heartwood norlignans of Cryptomeria japonica: evidence for independent control of agatharesinol and sequirin $\mathrm{C}$ biosynthesis. Annals of Forest Science, 2011, 68 (6), pp.1049-1056. 10.1007/s13595-011-0118-7 . hal-00930687

\section{HAL Id: hal-00930687 https://hal.science/hal-00930687}

Submitted on 1 Jan 2011

HAL is a multi-disciplinary open access archive for the deposit and dissemination of scientific research documents, whether they are published or not. The documents may come from teaching and research institutions in France or abroad, or from public or private research centers.
L'archive ouverte pluridisciplinaire HAL, est destinée au dépôt et à la diffusion de documents scientifiques de niveau recherche, publiés ou non, émanant des établissements d'enseignement et de recherche français ou étrangers, des laboratoires publics ou privés. 


\title{
Clonal variation in heartwood norlignans of Cryptomeria japonica: evidence for independent control of agatharesinol and sequirin $\mathrm{C}$ biosynthesis
}

\author{
Nobumasa Bito • Ryogo Nakada • Eitaro Fukatsu • \\ Yasuyuki Matsushita • Kazuhiko Fukushima • \\ Takanori Imai
}

Received: 21 December 2010 / Accepted: 6 June 2011 /Published online: 30 August 2011

(C) INRA and Springer Science+Business Media B.V. 2011

\begin{abstract}
- Introduction In Cryptomeria japonica, heartwood properties are considered to be affected by specific extractives. It remains unclear whether traits of specific heartwood compounds are under genetic control.

- Methods Two major heartwood norlignans, agatharesinol (A) and sequirin $\mathrm{C}(\mathrm{S})$, were determined quantitatively and qualitatively in 29 C. japonica plus-tree clones to evaluate their clonal variations and clonal repeatability.

- Results The content of two norlignans and their composition (S)mol/((A)mol + (S)mol) varied significantly depending on the clone, suggesting that the biosynthesis of norlignan is genetically regulated in C. japonica. In particular, the clonal repeatability of sequirin $C$ was higher than that of both agatharesinol and total norlignan content. In addition, the clonal repeatability of the norlignan molar ratio was quite high. These results suggested that genetic involvement is greater in the accumulation of sequirin $\mathrm{C}$ than agatharesinol. No significant correlation was found
\end{abstract}

Handling Editor: Jean-Michel Leban

N. Bito $\cdot$ T. Imai $(\bowtie)$

Laboratory of Biomass Resources Utilization,

Graduate School of Bioagricultural Sciences, Nagoya University,

Nagoya 464-8601, Japan

e-mail: takaimai@agr.nagoya-u.ac.jp

R. Nakada $\cdot$ E. Fukatsu

Forest Tree Breeding Center,

Forestry and Forest Products Research Institute,

3809-1 Ishi, Juo,

Hitachi 319-1301, Japan

Y. Matsushita $\cdot$ K. Fukushima

Laboratory of Forest Chemistry,

Graduate School of Bioagricultural Sciences, Nagoya University,

Nagoya 464-8601, Japan between agatharesinol and sequirin $\mathrm{C}$ content, or between the total norlignan content and the norlignan molar ratio, suggesting that the formation of agatharesinol and sequirin $\mathrm{C}$ in norlignan biosynthesis is independently controlled in $C$. japonica.

- Conclusions It was suggested that the traits of the specific heartwood extractive norlignans were under genetic control in C. japonica.

Keywords Biosynthesis · Clonal variation · Cryptomeria japonica $\cdot$ Heartwood extractives $\cdot$ Norlignan

\section{Introduction}

Chemical compounds of wood, especially heartwood extractives, may have critical roles in wood properties such as heartwood color and resistance against wood rots. Cryptomeria japonica D. Don (sugi or Japanese cedar) is an indigenous conifer in Japan and one of the most popular species for plantation forestry. A number of studies have identified the major $C$. japonica heartwood extractives, which are classified as norlignans and terpenoids (diterpenephenols). The norlignans in $C$. japonica heartwood are particularly associated with both normal heartwood color and discoloration of the heartwood, so-called black-heart or kuro-jin (Kai et al. 1972; Kai and Teratani 1977; Takahashi 1996, 1998; Ishiguri et al. 2003; Takahashi et al. 2003; Takahashi and Mori 2006). The heartwood norlignan sequirin $\mathrm{C}$ turns black on treatment with alkaline solution, indicating that it is involved in blackening (Takahashi and Mori 2006). The norlignans are also considered to contribute to resistance of the wood against butt-rot disease (Ohtani et al. 2009), termite feeding (Kano et al. 2004), and damage due to feeding by snails (Chen et al. 2001). 
Although heartwood extractives could affect some wood properties in $C$. japonica, the factors regulating their qualitative and quantitative variations have not been well investigated. Tamura et al. $(2004,2005)$ found that the yield of alcohol-benzene extracts from $C$. japonica heartwood varied depending on the clone and that genetic factors are likely to lead to improvement in carbon sequestration capacity. Shibutani et al. (2007) reported that the $C$. japonica heartwood terpenoid content is regulated not only by genetic factors but also by environmental factors, i.e., the growth sites of the trees. In other studies, the composition of $C$. japonica heartwood terpenoids was also reported to be regulated both genetically (Nagahama et al. 2001) and environmentally (Nagahama et al. 2002).

Ogiyama et al. (1983) surveyed norlignans in the heartwood of 432 C. japonica trees grown in 18 districts over almost all of the Japanese islands. They found that heartwood norlignan in C. japonica is composed mainly of agatharesinol and sequirin $\mathrm{C}$, accompanied occasionally by sugiresinol and hydroxysugiresinol (chemical structures in
Fig. 1), and that the composition did not vary significantly with growth site.

It is thought that in $C$. japonica the heartwood norlignans are formed in the intermediate wood, "the inner layers of the sapwood that are transitional between sapwood and heartwood in color and general character" as defined by IAWA (1964), and this part of the wood is observable as a narrow white zone, especially in $C$. japonica (Nobuchi and Harada 1983). The content of agatharesinol increases gradually from the middle part of intermediate wood toward the heartwood, whereas the content of sequirin $\mathrm{C}$ increases rapidly from the innermost intermediate wood toward the heartwood, indicating that the formation of agatharesinol is initiated at the middle stages of heartwood formation, followed by the formation of sequirin $\mathrm{C}$ at the latest stage of heartwood formation (Imai et al. 2005). Recently, Imai et al. (2009) demonstrated in vitro hydroxylation of agatharesinol to sequirin $\mathrm{C}$ using a microsomal preparation from $C$. japonica intermediate wood. In particular, the hydroxylase activity was higher on the
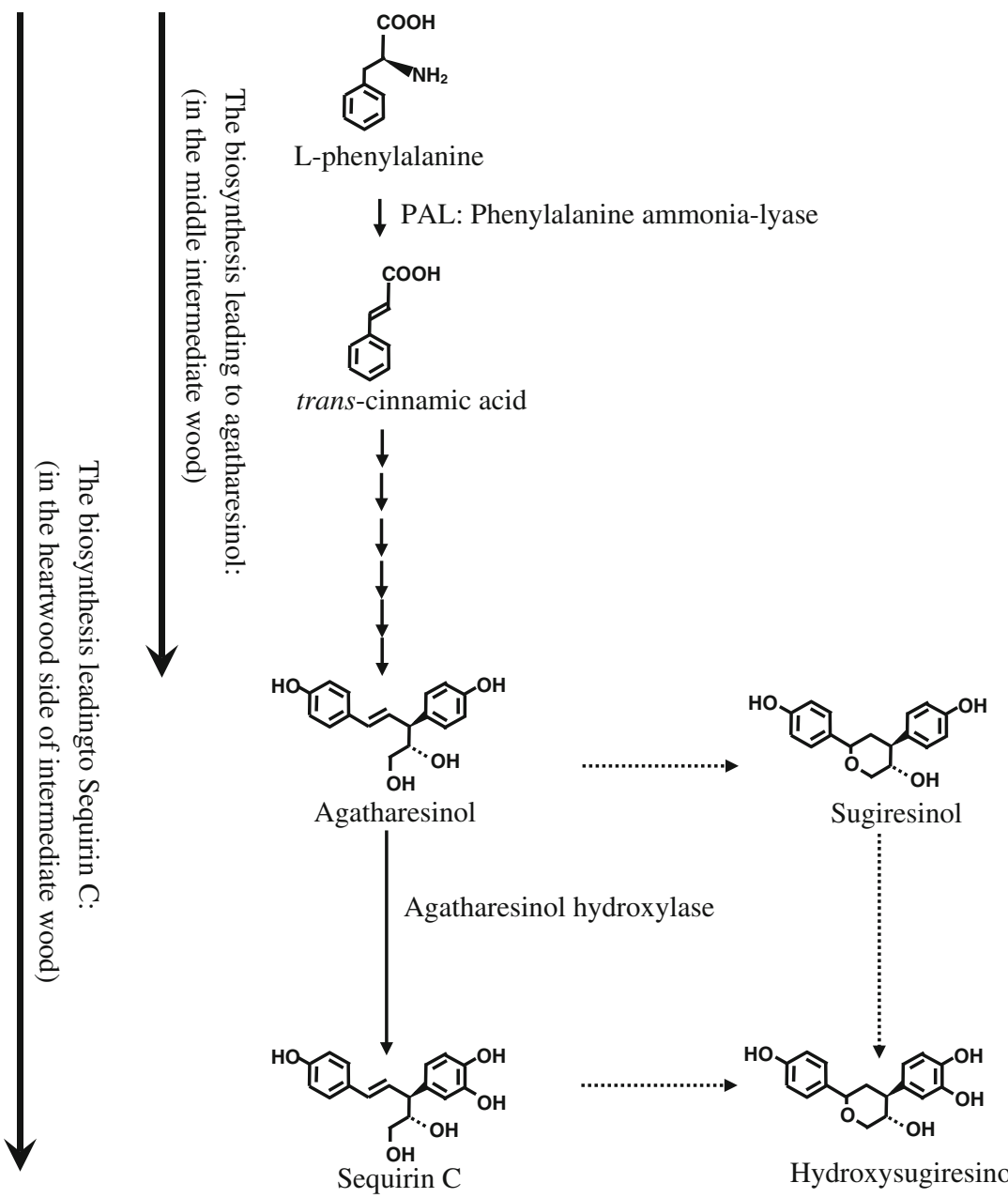

Fig. 1 Proposed biosynthetic pathway of norlignan 
heartwood side of intermediate wood, indicating that the conversion of agatharesinol to sequirin $\mathrm{C}$ occurs at the later stage of heartwood formation. Thus, the two $C$. japonica norlignans change quantitatively and qualitatively during heartwood formation.

Because the formation and accumulation of heartwood extractives are among the most remarkable changes during heartwood formation, qualitative and quantitative variations in norlignan could reflect major factor affecting variation during heartwood formation and affect consequential variation in its properties. Environmental influences on qualitative variation in $C$. japonica heartwood norlignans have been investigated (Ogiyama et al. 1983); however, neither the influence of the environment on quantitative variation nor the influence of genetics is well understood.

Although heritability or clonal variation of the amounts of heartwood extracts in tree species such as Pinus radiata (Shelbourne 1997), Pinus pinaster (Pot et al. 2002), and Eucalyptus globulus (Poke et al. 2006) have also been reported, such studies have not been well extensive. In particular, inheritance of the traits of specific heartwood compound is open to further investigation.

Our objective was to estimate genetic effects on regulation of the traits of specific heartwood extractive norlignans in $C$. japonica for the first time. Investigation of qualitative and quantitative variations in two major heartwood norlignans, agatharesinol and sequirin $\mathrm{C}$, in 29 C. japonica plus-tree clones led to the evaluation of clonal repeatability of the norlignan composition, which indicates the magnitude of their inheritance (van Buijtenen 1992). The influence of genetics on the variation is discussed. In addition, the association of norlignan traits (norlignan content and norlignan composition) with four conventional selection traits (tree height, diameter at breast height (DBH), wood density, and heartwood moisture content) is discussed to estimate the influence of selection for these conventional traits during breeding on norlignan diversity.

\section{Materials and methods}

\subsection{Materials}

Plus-tree clones of Cryptomeria japonica had been planted in clonal archives at the Okubo Breeding Material Management Garden of the Forest Tree Breeding Center, Forestry and Forest Product Research Institute in Hitachi, Ibaraki Prefecture, Japan. The clonal archives were established in 1994 under a row plot design, in which seven ramets (individual trees in each clone) are planted in one row without any replication. Plus-trees are selected based on their superior growth and stem form in the Japanese tree breeding program. A $40-\mathrm{m}^{2}$ study plot was selected from a 2.8-ha clonal archive. The study plot consisted of four subplots including 11 to 13 clones each. The spacing of planting was $1.1 \mathrm{~m}$ between ramets within a row (one clone per one row), $3.0 \mathrm{~m}$ between rows (clones), and $3.0 \mathrm{~m}$ between subplots. Therefore, the stocking was ca. 2,300 stems per hectare. A total of 29 clones, including 22 clones selected from Fukushima Prefecture and seven clones from Kochi Prefecture, were used. The trees selected for investigation were average sized trees within the clone that had the least damage by insects or weather hazards.

Average tree height and average diameter at breast height (with coefficient of variation in parentheses) of the sample trees were $10.5 \mathrm{~m}(14.7 \%)$ and $16.1 \mathrm{~cm}(21.0 \%)$, respectively. From 85 trees (three ramets from 27 clones and two ramets from two clones), increment cores were collected at breast height with an increment borer (inner diameter, $5 \mathrm{~mm}$ ) in May 2008, and were divided into heartwood, sapwood, and intermediate wood based on color. Samples were stored in methanol containing $0.1 \%(w / w)$ ascorbic acid at $4^{\circ} \mathrm{C}$ until use. Wood disks were obtained from the same trees at breast height in November 2008 for the measurement of wood density and heartwood moisture content. Fan-shaped wood blocks (fan-shape $\times$ height: $r=3-5 \mathrm{~cm}, \theta=10^{\circ}, h=5 \mathrm{~cm}$ (approx.)) were taken from heartwood where no effect of core sampling was observed, and the fresh weight was measured immediately after felling the sample trees. The oven-dried (at $105^{\circ} \mathrm{C}$ until the measured mass was stable) heartwood density was determined by the mercury displacement method as the value of oven-dried weight per oven-dried volume. The moisture content $(\mathrm{MC})$ of the specimen was determined as follows: $\mathrm{MC}=(\mathrm{Wg}-\mathrm{Wd}) / \mathrm{Wd}$, where $\mathrm{Wg}$ is the fresh weight and $\mathrm{Wd}$ is the oven-dried weight.

\subsection{Extraction and gas chromatography-mass spectrometry analysis}

The heartwood samples from increment cores were cut into small pieces with a knife, and then extracted thoroughly with hot $\left(55^{\circ} \mathrm{C}\right)$ methanol $(\mathrm{MeOH})$ for 4 days, during which solvent was exchanged twice a day. All $\mathrm{MeOH}$ solutions and the prestorage $\mathrm{MeOH}$ solution (mentioned in Section 2.1) obtained from each sample were combined and evaporated to give a residue $(\mathrm{MeOH}$ extract). The $\mathrm{MeOH}$ extracts were extracted with ethyl acetate (EtOAc), and the EtOAc solutions were evaporated to give EtOAc extracts. A portion of the EtOAc extract was dissolved in pyridine, and an aliquot of the solution was trimethylsilylated using $\mathrm{N}, \mathrm{O}$-bis (trimethylsilyl)-trifluoroacetamide (Wako, Japan). The trimethylsilyl derivatives were analyzed by gas chromatographymass spectrometry (GC-MS) on a Shimadzu GC-MS QP 2010 Plus instrument (Shimadzu, Kyoto, Japan) equipped with a DB-1 capillary column $(30 \mathrm{~m} \times 0.32 \mathrm{~mm}$, i.d.; film thickness, $1 \mu \mathrm{m}$ ) using helium gas as the mobile phase. The 
oven temperature was $280^{\circ} \mathrm{C}$, and the ionization energy was $70 \mathrm{eV}$. Chromatogram peaks were assigned by comparing their retention times and mass fragmentation patterns with those of authentic samples. The content of agatharesinol and sequirin $\mathrm{C}$ was determined using 4,4'-dihydroxychalcone as an internal standard.

\subsection{Statistical analysis}

One-way analysis of variance (ANOVA) was used to test for significance of the genetic (clonal) involvement in the variation in norlignan content and norlignan composition. Clonal repeatability was calculated as an indicator of the magnitude of inheritance as follows:

$h^{2}=\sigma_{\mathrm{c}}^{2} /\left(\sigma_{\mathrm{c}}^{2}+\sigma_{\mathrm{e}}^{2}\right)$

where $h^{2}$ is the clonal repeatability, $\sigma_{\mathrm{c}}{ }^{2}$ is the variance due to interclonal differences, and $\sigma_{\mathrm{e}}{ }^{2}$ is the error variance. Standard error for the heritability of each trait was calculated using the delta method (Lynch and Walsh 1998). The estimation of variances and standard errors was carried out using ASReml software (Gilmour et al. 2009).

Because each clone was planted in only one row with several ramets, there was no environmental replication. Therefore, it was not possible to separate the variance due to genotype from variance due to that portion of environmental effects that might have varied orthogonally along the row in the clonal archive. Estimates of clonal repeatability were thus conducted assuming that the environmental effects influencing norlignan content were randomly distributed over the site.

Pearson product-moment correlation on coefficients between norlignan traits (norlignan content and norlignan composition) and conventional selection traits (tree height, DBH, wood density, and heartwood moisture content) were calculated based on 29 C. japonica plus-tree clonal averages.

\section{Results}

GC-MS analysis demonstrated that agatharesinol and sequirin $\mathrm{C}$ were the major norlignans in all 85 C. japonica heartwood samples; neither sugiresinol nor hydroxysugiresinol was detected in any samples, consistent with a previous report that $C$. japonica wood only infrequently contains sugiresinol and hydroxysugiresinol (Ogiyama et al. 1983). In this study, therefore, the total content of heartwood norlignan was expressed as the sum of agatharesinol and sequirin $\mathrm{C}$ content ( $\mu \mathrm{mol} / \mathrm{g}$ of oven-dried sample weight). The composition of heartwood norlignan was expressed as the molar ratio of agatharesinol (A) to sequirin $\mathrm{C}(\mathrm{S})$ : $\mathrm{S}(\mathrm{mol}) /(\mathrm{A}(\mathrm{mol})+\mathrm{S}(\mathrm{mol}))$. The total norlignan content should represent the ability of the norlignan biosynthetic pathway to form agatharesinol and the norlignan molar ratio should represent the activity of agatharesinol hydroxylase in the conversion of agatharesinol to sequirin C (Fig. 1).

Quantitative variation in heartwood norlignan was shown by the frequency distribution of agatharesinol content, sequirin
Fig. 2 a-d Frequency distribution of a total norlignan content, b agatharesinol content, c sequirin $\mathrm{C}$ content, and $\mathbf{d}$ norlignan molar ratio $(\mathrm{S}(\mathrm{mol}) /$ $(\mathrm{A}(\mathrm{mol})+\mathrm{S}(\mathrm{mol})))$ in 85 samples
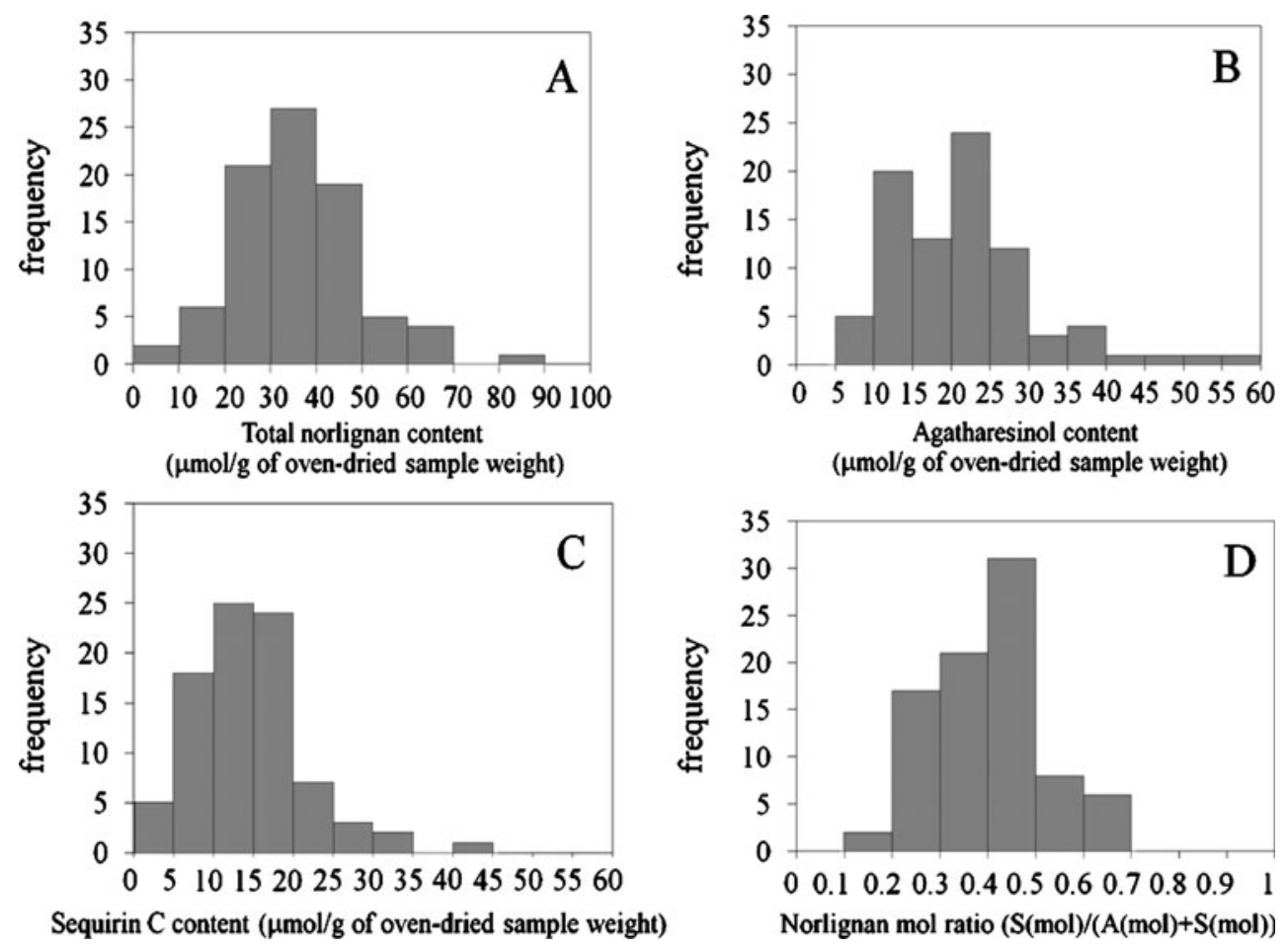

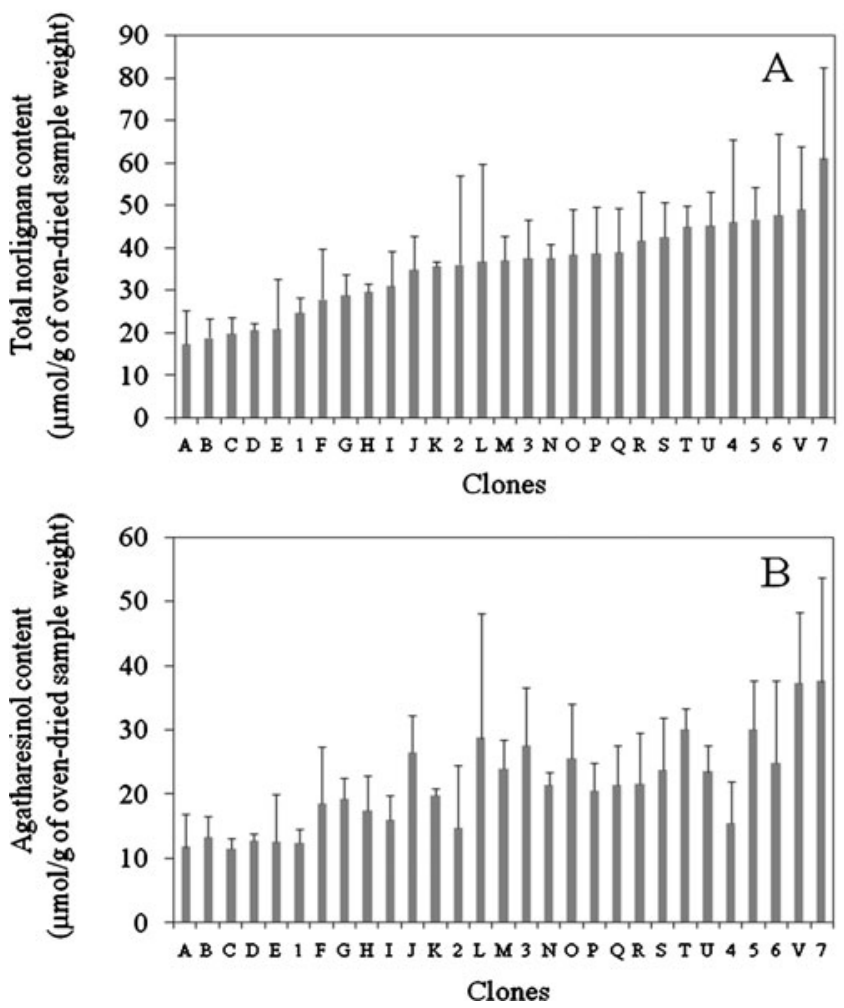

Fig. 3 Clonal variations of a total norlignan content, $\mathbf{b}$ agatharesinol content, $\mathbf{c}$ sequirin $\mathrm{C}$ content, and $\mathbf{d}$ norlignan ratio among the $29 \mathrm{C}$. japonica plus-tree clones. Error bars show standard deviation. Plus-

C content, and total norlignan content, and qualitative variation was shown by the frequency distribution of the norlignan molar ratio $(\mathrm{S} /(\mathrm{A}+\mathrm{S}))$ among the 85 C. japonica heartwood samples (Fig. 2a-d). The coefficients of variation (standard deviation/mean value) of agatharesinol, sequirin $\mathrm{C}$, and total norlignan content were $45 \%, 50 \%$, and $39 \%$, respectively, and that of the norlignan molar ratio was $28 \%$.

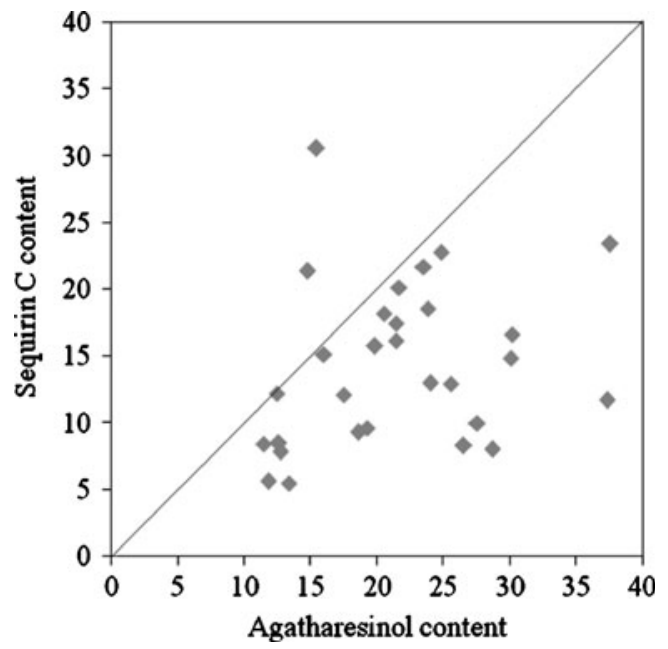

Fig. 4 Relation between agatharesinol content and sequirin $\mathrm{C}$ content. All 29 clonal means are plotted. $r=0.237 ; p>0.05$. The diagonal line shows $x=y$
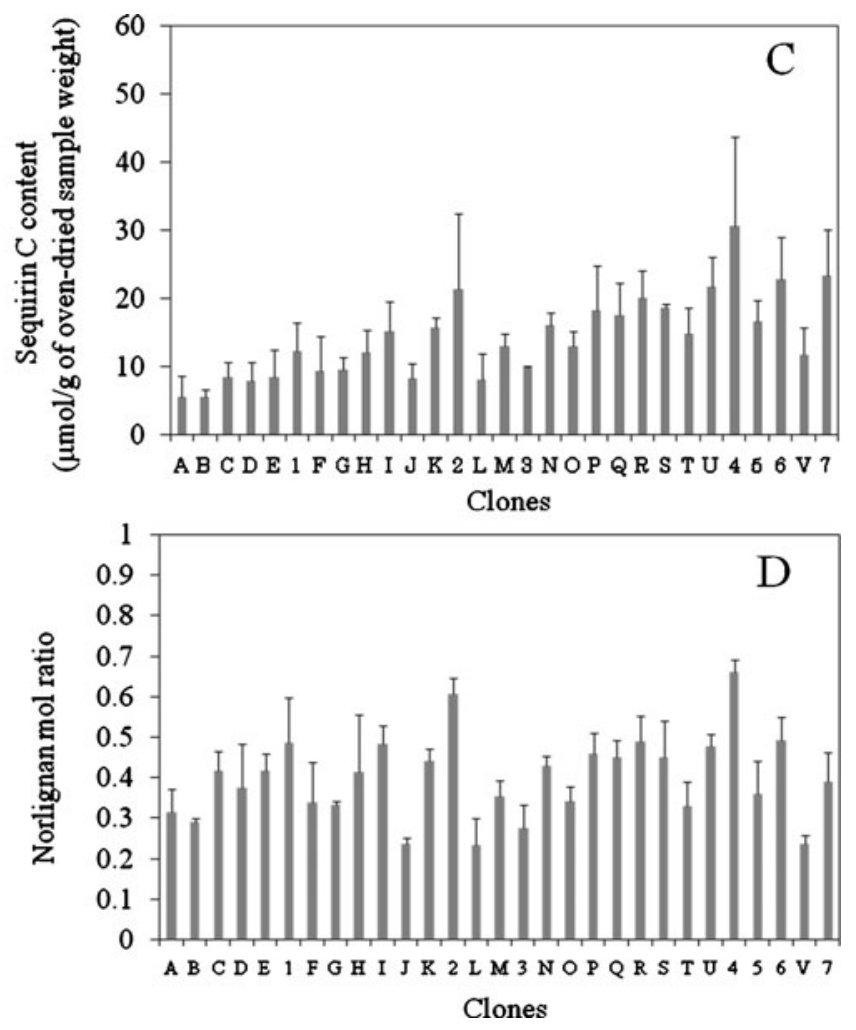

tree clones from Fukushima Pref. are indicated as letters and those from Kochi Pref. as numbers. The order of the clone in the figures follows the total norlignan content

The clonal average agatharesinol content varied from 11.5 to $37.6 \mu \mathrm{mol} / \mathrm{g}(0.33 \%$ to $1.07 \%(w / w))$, sequirin $\mathrm{C}$ content from 5.5 to $30.6 \mu \mathrm{mol} / \mathrm{g}(0.17 \%$ to $0.92 \%(w / w))$, and total norlignan content from 17.4 to $61.0 \mu \mathrm{mol} / \mathrm{g}(0.51 \%$ to $1.78 \%$ $(w / w))$ (Fig. 3a-c). The total average of agatharesinol, sequirin $\mathrm{C}$, and total norlignan content were $21.4,14.3$, and $35.7 \mu \mathrm{mol} / \mathrm{g}$, respectively $(0.61 \%, 0.43 \%$, and $1.05 \%(w / w))$.

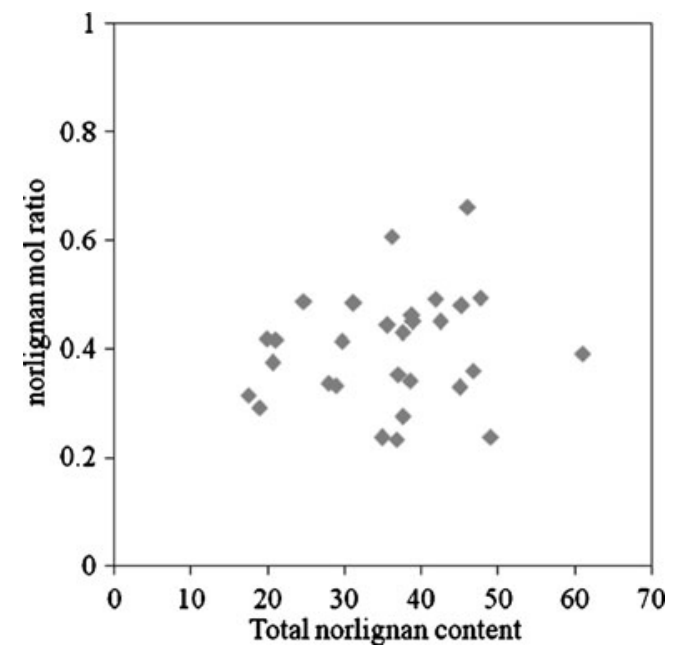

Fig. 5 Relation between the total norlignan content and the norlignan molar ratio. All 29 clonal means are plotted. $r=0.155 ; p>0.05$ 
Table 1 Analysis of variance for norlignan content and norlignan molar ratio of $C$. japonica plus-tree clones

\begin{tabular}{|c|c|c|c|c|c|c|}
\hline Factor & SS & $d f$ & MS & $F$ value & $P$ value & $\begin{array}{l}\text { Clonal repeatability } \\
\text { (standard error) }\end{array}$ \\
\hline \multicolumn{7}{|c|}{ Agatharesinol content } \\
\hline Clones & 4,298 & 28 & 153.5 & 2.44 & $<0.01$ & $0.33(0.12)$ \\
\hline Residuals & 3,517 & 56 & 62.81 & & & \\
\hline \multicolumn{7}{|c|}{ Sequirin $\mathrm{C}$ content } \\
\hline Clones & 3,028 & 28 & 108.1 & 4.54 & $<0.001$ & $0.55(0.10)$ \\
\hline Residuals & 1,333 & 56 & 23.81 & & & \\
\hline \multicolumn{7}{|c|}{ Total norlignan content } \\
\hline Clones & 8,913 & 28 & 318.3 & 2.38 & $<0.01$ & $0.32(0.12)$ \\
\hline Residuals & 7,485 & 56 & 133.7 & & & \\
\hline \multicolumn{7}{|c|}{ Norlignan molar ratio } \\
\hline Clones & 0.882 & 28 & 0.0315 & 8.49 & $<0.001$ & $0.72(0.08)$ \\
\hline Residuals & 0.208 & 56 & 0.0037 & & & \\
\hline
\end{tabular}

$S S$ sum of squares, $d f$ degrees of freedom, $M S$ mean squares clonal repeatability of tree height, $\mathrm{DBH}$, heartwood density, and heartwood moisture content was 0.61 (0.10), 0.31 $(0.12), 0.34(0.12)$, and $0.40(0.12)$, respectively.

Table 2 shows correlation coefficients between the norlignan traits and the four conventional selection traits. No significant correlation was found between the norlignan and selection traits (Table $2 ; p>0.05$ ), except for a low correlation between the total norlignan content and heartwood density $(r=0.383 ; p<0.05)$ and between agatharesinol content and heartwood density $(r=0.396 ; p<0.05)$.

\section{Discussion}

Qualitative variation in C. japonica heartwood norlignan and environmental influences on this variation have been studied (Ogiyama et al. 1983). In the present study, we investigated genetic involvement in the quantitative and qualitative variation in heartwood norlignan using $C$. japonica plus-tree clones.

One-way ANOVA (Table 1) revealed apparent clonal variations in agatharesinol content $(p<0.01)$, sequirin $\mathrm{C}$ content

Table 2 Pearson product-moment correlation on coefficients between norlignan traits and conventional selection traits of 29 C. japonica plus-tree clones $(n=29)$

\begin{tabular}{lcccc}
\hline Conventional selection traits & \multicolumn{2}{l}{ Norlignan traits } & & \\
\cline { 2 - 5 } & Total norlignan content & Agatharesinol content & Sequirin C content & Norlignan molar ratio \\
\hline Tree height & $-0.167 \mathrm{~ns}$ & $-0.179 \mathrm{~ns}$ & $-0.076 \mathrm{~ns}$ & $0.017 \mathrm{~ns}$ \\
DBH & $-0.200 \mathrm{~ns}$ & $-0.252 \mathrm{~ns}$ & $-0.046 \mathrm{~ns}$ & $0.101 \mathrm{~ns}$ \\
Heartwood density & $0.383^{*}$ & $0.396^{*}$ & $0.190 \mathrm{~ns}$ & $-0.030 \mathrm{~ns}$ \\
Heartwood moisture content & $0.157 \mathrm{~ns}$ & $0.042 \mathrm{~ns}$ & $0.221 \mathrm{~ns}$ & $0.131 \mathrm{~ns}$ \\
\hline
\end{tabular}

$n s$ not significant at $p=0.05$

$* 0.01<p<0.05$, significant 
$(p<0.001)$, total norlignan content $(p<0.01)$, and norlignan molar ratio $(p<0.001)$. These results strongly suggest that the accumulation of norlignan is genetically regulated in $C$. japonica. The clonal repeatability of the norlignan composition was similar to that of heartwood extracts of $C$. japonica (Tamura et al. 2005).

As Imai et al. (2009) demonstrated recently in vitro, sequirin $\mathrm{C}$ is biosynthesized by a one-step enzymatic hydroxylation of agatharesinol, which is biosynthesized through multi-step enzymatic reactions in the phenylpropanoid pathway (Fig. 1, Imai et al. 2006a, b). Although the biosynthesis of sequirin $\mathrm{C}$ requires one additional step beyond agatharesinol, the clonal repeatability of sequirin $\mathrm{C}$ content $\left(h^{2}=0.55\right)$ was higher than that of both agatharesinol content $\left(h^{2}=0.33\right)$ and total norlignan content $\left(h^{2}=0.32\right.$; Table 1). In addition, the clonal repeatability of the norlignan molar ratio was quite high $\left(h^{2}=0.72\right.$; Table 1$)$. These results suggest that genetic involvement in the accumulation of sequirin $\mathrm{C}$ is more significant than that of agatharesinol, which is likely attributable to high genetic regulation of agatharesinol hydroxylase activity.

Significant correlations were not found between agatharesinol content and sequirin C content (Fig. 4), or between the total norlignan content and the norlignan molar ratio (Fig. 5). These results suggest that the biosynthetic steps leading to agatharesinol formation and the following conversion of agatharesinol to sequirin $\mathrm{C}$ is regulated separately, resulting in independent control of biosynthesis of these two norlignans in $C$. japonica; sequirin $\mathrm{C}$ biosynthesis might be regulated apart from agatharesinol biosynthesis in spite of sequirin $\mathrm{C}$ being formed through agatharesinol as a biosynthetic intermediate (Imai et al. 2009). This hypothesis of independent control of the biosynthesis is supported by previous studies: Ohashi and Imai (1990) and Ohashi et al. (1990) found that agatharesinol accumulated in the sapwood of $C$. japonica stem logs allowed to stand after cutting the trees down, and Imai et al. (2005, 2006a, b) found that agatharesinol accumulated in sapwood sticks of $C$. japonica kept under high humidity after preparing the sticks from fresh wood. It is assumed that the biosyntheses of heartwood extractives including norlignan occurs in dying ray parenchyma cells in intermediate wood during the transition from sapwood to heartwood. Therefore, Imai et al. concluded that the accumulation of agatharesinol in the sapwood must be due to biological action, probably by dying ray parenchyma cells, which would resemble the phenomenon in intermediate wood. In these experiments, however, sequirin $\mathrm{C}$ was not accumulated in the sapwood. Thus, the biosynthesis of agatharesinol can be induced experimentally, but the following one-step conversion of agatharesinol to sequirin $\mathrm{C}$ has never occurred.

Nobuchi and Harada (1983) reported that the percentage of dead parenchyma cells increased gradually from the sapwood side toward the heartwood side in intermediate wood of $C$. japonica. This observation demonstrates that in intermediate wood cells, aging cells gradually progress toward cell death, and in this process, ray parenchyma cells alter their physiological functions. In particular, sequirin $\mathrm{C}$ biosynthetic ability must develop after cell aging has progressed substantially, because the content of sequirin $\mathrm{C}$ increases rapidly from the innermost intermediate wood toward the heartwood, indicating preferential formation of sequirin $\mathrm{C}$ at the later stage of heartwood formation (Imai et al. 2005, 2009). Furthermore, the ray parenchyma cells in $C$. japonica intermediate wood might have a different physiological ability for sequirin $\mathrm{C}$ biosynthesis, depending on the position of the ray cells, as Nakaba et al. (2006, 2008) observed in Abies sachalinensis, Pinus densiflora, and Pinus rigida. Nakaba et al. proposed that the differentiation and cell death of ray parenchyma cells starts in the upper or lower radial cell lines of a ray. Thus, the spatial and temporal dynamics of the biosynthesis of norlignan during heartwood formation should also be taken into consideration as well as regulation of agatharesinol hydroxylase activity to understand the variation in heartwood norlignan.

Almost no correlations were significant between norlignan traits (norlignan content and norlignan molar ratio) and conventional selection traits (tree height, DBH, and wood density) (Table 2), suggesting that norlignan accumulation is not genetically associated with these traits. Therefore, the diversity of norlignan accumulation in heartwood will not be lessened even when tree breeding programs improve the conventional selection traits associated with cell wall formation.

To the best of our knowledge, this is the first report suggesting genetic control of the traits of specific heartwood norlignans in $C$. japonica. Further studies are under way to reveal the inheritance of norlignan traits precisely using control-pollinated families of $C$. japonica.

Acknowledgment We acknowledge the assistance of FTBC staff for sampling.

Funding This work was supported by a Grant-in-Aid for Scientific Research (no. 20248018) from the Japan Society for the Promotion of Science.

\section{References}

Chen XH, Kim CS, Kashiwagi T, Tebayashi S, Horiike M (2001) Antifeedants against Acusta despesta from the Japanese cedar, Cryptomeria japonica II. Biosci Biotechnol Biochem 65:14341437. doi:10.1271/bbb. 65.1434

Gilmour AR, Gogel BJ, Cullis BR, Thompson R (2009) ASReml User Guide Release 3.0 VSN International Ltd, Hemel Hempstead, HP1 1ES, UK. Available at: www.vsni.co.uk

IAWA (Committee on Nomenclature, International Association of Wood Anatomists) (1964) Multilingual glossary of terms used in wood anatomy. Verlag Sanstalt Buchdruckrei Konkordia, Wintherthur 
Imai T, Ito E, Fukushima K (2005) Biochemical studies of matured xylem of Cryptomeria japonica: attempts to detect the enzymes involved in the biosyntheses of the heartwood extractives. Nagoya Univ For Sci 24:1-6

Imai T, Nomura M, Fukushima K (2006a) Evidence for involvement of the phenylpropanoid pathway in the biosynthesis of the norlignan agatharesinol. J Plant physiol 163:483-487. doi:10.1016/j.jplph.2005.08.009

Imai T, Nomura M, Matsushita Y, Fukushima K (2006b) Hinokiresinol is not a precursor of agatharesinol in the norlignan biosynthetic pathway in Japanese cedar. J Plant physiol 163:1221-1228. doi:10.1016/j.jplph.2006.05.012

Imai T, Asai K, Takino M, Fukushima K (2009) In vitro hydroxylation of a norlignan: from agatharesinol to sequirin $\mathrm{C}$ and metasequirin $\mathrm{C}$ with a microsomal preparation from Cryptomeria japonica. Phytochem Lett 2:196-200. doi:10.1016/j.phytol.2009.07.002

Ishiguri F, Maruyama S, Takahashi K, Abe Z, Yokota S, Andoh M, Yoshizawa N (2003) Extractives relating to heartwood color changes in sugi (Cryptomeria japonica) by a combination of smoke-heating and UV radiation exposure. J Wood Sci 49:135139. doi: $10.1007 / \mathrm{s} 100860300021$

Kai Y, Teratani F (1977) Studies on the color of the heartwood of sugi (Cryptomeria japonica). I. Characterization and content of methanol insoluble pigment in heartwood. Mokuzai Gakkaishi 23:499-503

Kai Y, Kuroda H, Teratani F (1972) On the phenolic constituents from Cryptomeria japonica D. Don. VI. Hydroxysugiresinol and coloration of heartwood. Mokuzai Gakkaishi 18:315-321

Kano H, Shibutani S, Hayashi K, Iijima Y, Doi S (2004) Effect of high-temperature drying processes on termite resistance of sugi (Cryptomeria japonica) heartwood. Mokuzai Gakkaishi 50:91-98

Lynch M, Walsh B (1998) Genetics and analysis of quantitative traits. Sinauer Associates, Sunderland

Nagahama S, Tukamoto T, Torii N, Sonoda T, Yamanobe T (2001) Terpenoids of the wood oil of sugi (Cryptomeria japonica). VII: components of elite clones Minamatasho-4, and five others. Mokuzai Gakkaishi 47:487-492

Nagahama S, Fujii H, Sonoda T, Sasaki M (2002) Terpenoids of the wood oil of sugi (Cryptomeria japonica). VIII: components of KenKunisaki-5 and five other elite clones. Mokuzai Gakkaishi 48:380-386

Nakaba S, Sano Y, Kubo T, Funada R (2006) The positional distribution of cell death of ray parenchyma in a conifer, Abies sachalinensis. Plant Cell Rep 25:1143-1148. doi:10.1007/ s00299-006-0194-6

Nakaba S, Kubo T, Funada R (2008) Differences in patterns of cell death between ray parenchyma cells and ray tracheids in the conifers Pinus densiflora and Pinus rigida. Trees 22:623-630. doi:10.1007/s00468-008-0220-0

Nobuchi T, Harada H (1983) Physiological features of the "white zone" of sugi (Cryptomeria japonica D. Don): cytological structure and moisture content. Mokuzai Gakkaishi 29:824-832
Ogiyama K, Yasue M, Takahashi K (1983) Chemosystematic study on heartwood extractives of Cryptomeria japonica D. Don. In: Proc of Int Symp on Wood and Pulping Chem, Tsukuba. Vol. 1. pp. 101-106

Ohashi H, Imai T (1990) Characterization of physiological function of sapwood: synthesis and accumulation of heartwood extractives in the withering process of immature Japanese cedar trunk. Holzforsch 44:317-323. doi:10.1515/hfsg.1990.44.5.317

Ohashi H, Imai T, Yoshida K, Yasue M (1990) Characterization of physiological functions of sapwood: fluctuation of extractives in the withering process of Japanese cedar sapwood. Holzforsch 44:79-86. doi:10.1515/hfsg.1990.44.2.79

Ohtani Y, Noguchi T, Ichiura H (2009) Relationship between sugi buttrot disease and norlignans in the heartwood. Mokuzai Gakkaishi 55:92-100

Poke FS, Potts BM, Vaillancourt RE, Raymond CA (2006) Genetic parameters for lignin, extractives and decay in Eucalyptus globulus. Ann For Sci 63:813-821. doi:10.1051/forest:20000006080

Pot D, Chantre G, Rozenberg P, Rodrigues C, Jones GL, Pereira H, Hannrup B, Cahalan C, Plomion C (2002) Genetic control of pulp and timber properties in maritime pine (Pinus pinaster Ait.). Ann For Sci 59:563-575. doi:10.1051/forest:2002042

Shelbourne CJA (1997) Genetics of adding value to the end-products of radiata pine. In: Proc of Int Union of For Res Organ, Rotorua. pp. 129-141

Shibutani S, Takata K, Doi S (2007) Quantitative comparisons of antitermite extractives in heartwood from the same clones of Cryptomeria japonica planted at two different sites. J Wood Sci 53:285-290. doi:10.1007/s10086-006-0866-4

Takahashi K (1996) Relationships between the blackening phenomenon and norlignans of sugi (Cryptomeria japonica D. Don) heartwood. I. A case of partially black heartwood. Mokuzai Gakkaishi 42:9981005

Takahashi K (1998) Relationships between the blackening phenomenon and norlignans of sugi (Cryptomeria japonica D. Don) heartwood II. Mokuzai Gakkaishi 44:125-133

Takahashi K, Mori K (2006) Relationships between blackening phenomenon and norlignans of sugi (Cryptomeria japonica) heartwood. III: coloration of norlignans with alkaline treatment. J Wood Sci 52:134-139. doi:10.1007/s10086-005-0733-8

Takahashi K, Andoh M, Yokota S, Abe Z, Yoshizawa N (2003) Prevention of sugi (Cryptomeria japonica D. Don) from turning black by smoke heating. Wood Fiber Sci 35:209-216

Tamura A, Fujisawa Y, Iizuka K (2004) Longitudinal quantitative variation of heartwood extractives in sugi (Cryptomeria japonica) plus-tree clones. Mokuzai Gakkaishi 50:236-242

Tamura A, Fujisawa Y, Iizuka K, Kubota M (2005) Influence of heartwood extractives on carbon content variations among clones in the heartwood of sugi (Cryptomeria japonica). Mokuzai Gakkaishi 51:257-264

van Buijtenen JP (1992) Fundamental genetic principles. In: Fin L et al (eds) Handbook of quantitative forest genetics. Kluwer, Dordrecht, pp 26-68 